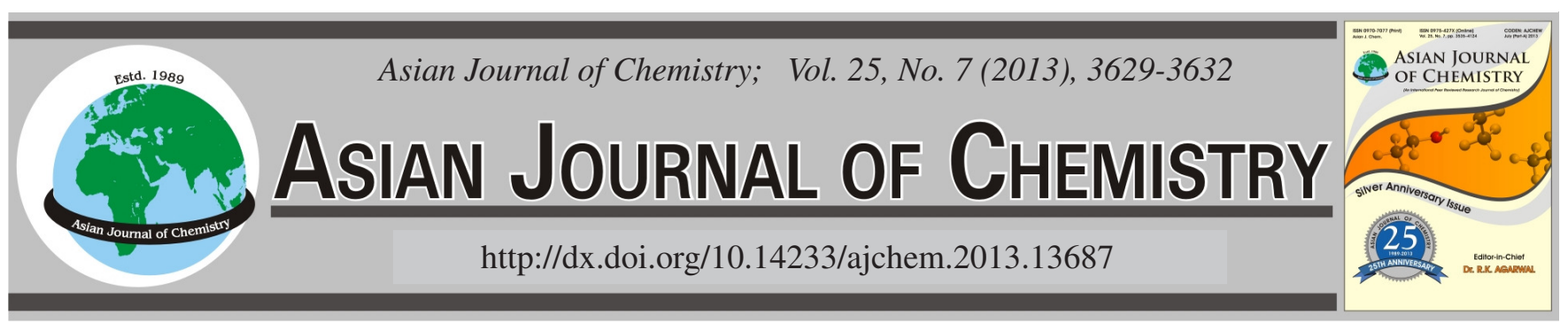

\title{
Synthesis and Cytotoxicity of Coumarin Derivatives and Nordentatin
}

\section{Pawantree Promsuwan and Chavi Yenjai*}

Natural Products Research Unit, Department of Chemistry and Center of Excellence for Innovation in Chemistry, Faculty of Science, Khon Kaen University, Khon Kaen 40002, Thailand

*Corresponding author: Fax: +66 4320 2373; Tel: +66 4320 2222-41, Ext. 12243; E-mail: chayen@kku.ac.th

Nordentatin and 10 coumarin derivatives were synthesized and evaluated for cytotoxicity. Compounds 6, 7, 9 and 13 showed cytotoxicity against the NCI-H187 cell line with $\mathrm{IC}_{50}$ value ranging of 3-7 $\mu \mathrm{g} / \mathrm{mL}$. Among synthesized coumarins, compounds 4 and 13 demonstrated cytotoxicity against the $\mathrm{KB}$ cell line with $\mathrm{IC}_{50}$ values of 3.94 and $6.44 \mu \mathrm{g} / \mathrm{mL}$, respectively. Fortunately, coumarins 4 and 7 may be one of the new lead compounds for the development of anticancer agents due to reason that they showed weak and inactive against normal cells.

Key Words: Nordentatin, Cytotoxicity, NCI-H187, KB, MCF-7, Vero cells.

\section{INTRODUCTION}

In continuation of our work on bioactive substances from natural sources, we have intensively screened the bioactivities of plants in Thailand. Structural modification of natural compounds such as flavonoids ${ }^{1}$, sesquiterpenes ${ }^{2}$ and carbazoles ${ }^{3}$ have been studied and evaluated for bioactivities. In previous investigations of the chemical constituents of Clausena harmandiana, carbazoles and coumarins have been isolated and evaluated for many activities such as antiplasmodial ${ }^{4}$, antifungal, anti TB, cytotoxic ${ }^{5,6}$ and antidiabetic ${ }^{7}$. It has been reported that coumarins exhibit antibacterial and antitumor promoting action and have an inhibitory effect on iNOS protein expression ${ }^{8}$. Nordentatin, a coumarin from this plant, showed significant glucose uptake activity in L9 myotubes in a time and dose dependent manner ${ }^{7}$. In addition, nordentatin was inhibited by phosphatidylinositol 3-kinases and showed significant toxicity to P-388 cells with $\mathrm{EC}_{50}$ value of $0.26 \mathrm{mg} / \mathrm{mL}^{9}$. It has been reported that this compound shows antibacterial activity and displays more potent NO-reducing activity in microglial cells ${ }^{10}$. This compound suppressed hepatitis B virus surface antigen in HepA2 cells and showed cytotoxicity against human cancer cells, A549 ${ }^{11}$. In the present work, we tried to synthesize nordentatin from 5,7-dimethoxycoumarin which was obtained from the reaction of phloroglucinol (1) and ethyl propiolate (2). All coumarin derivatives obtained from the reactions were evaluated for cytotoxicity against cancer cells, NCI-H187, MCF-7 and KB cell lines and noncancer cell, Vero cells (Table-1).

\begin{tabular}{|c|c|c|c|c|}
\hline \multicolumn{5}{|c|}{$\begin{array}{c}\text { TABLE-1 } \\
\text { CYTOTOXICITY OF ALL COMPOUNDS }\end{array}$} \\
\hline \multirow{2}{*}{ Compound } & \multicolumn{4}{|c|}{ Cytotoxicity $\left(\mathrm{IC}_{50} \mu \mathrm{g} / \mathrm{mL}\right)$} \\
\hline & NCI-H187 & MCF-7 & $\mathrm{KB}$ & Vero cells \\
\hline 3 & Inactive $^{\mathrm{a}}$ & Inactive $^{\mathrm{a}}$ & Inactive $^{a}$ & Inactive $^{\mathrm{a}}$ \\
\hline 4 & 34.95 & Inactive $^{a}$ & 3.94 & 47.04 \\
\hline 5 & 11.31 & Inactive $^{\mathrm{a}}$ & 48.29 & 41.45 \\
\hline 6 & 5.18 & 18.65 & 14.42 & 18.27 \\
\hline 7 & 5.78 & Inactive $^{\mathrm{a}}$ & 17.34 & Inactive $^{\mathrm{a}}$ \\
\hline 8 & Inactive $^{\mathrm{a}}$ & Inactive $^{a}$ & 21.48 & 19.14 \\
\hline 9 & 7.39 & 21.52 & 12.49 & 17.20 \\
\hline 10 & Inactive $^{\mathrm{a}}$ & Inactive $^{\mathrm{a}}$ & Inactive $^{a}$ & Inactive $^{a}$ \\
\hline 11 & 13.90 & 22.55 & 26.00 & 21.83 \\
\hline 12 & 13.60 & 25.84 & 25.53 & 24.87 \\
\hline 13 & 3.69 & 10.68 & 6.44 & 17.60 \\
\hline Ellipticine & 1.05 & - & 1.27 & 1.02 \\
\hline Doxorubicin & - & 8.02 & - & - \\
\hline
\end{tabular}

*Data shown are from triplicate experiments. ${ }^{a}$ Inactive at $>50 \mu \mathrm{g} / \mathrm{mL}$.

\section{EXPERIMENTAL}

NMR spectra were recorded on a Varian Mercury plus spectrometer operating at $400 \mathrm{MHz}\left({ }^{1} \mathrm{H}\right)$ and at $100 \mathrm{MHz}\left({ }^{13} \mathrm{C}\right)$. IR spectra were recorded as $\mathrm{KBr}$ disks using a Perkin Elmer Spectrum One FT-IR spectrophotometer. Mass spectra were determined on a Micromass Q-TOF 2 hybrid quadrupole timeof-flight (Q-TOF) mass spectrometer with a Z-spray ES source (Micromass, Manchester, UK). Melting points were determined on a SANYO Gallenkamp melting point apparatus and were uncorrected. Thin layer chromatography (TLC) was carried out on MERCK silica gel $60 \mathrm{~F}_{254}$ TLC aluminum sheet. 
Column chromatography was done with silica gel 0.063-0.200 $\mathrm{mm}$ or less than $0.063 \mathrm{~mm}$. Preparative layer chromatography was carried out on glass supported silica gel plates using silica gel $60 \mathrm{PF}_{254}$ for preparative layer chromatography. All solvents were routinely distilled prior to use.

\section{Synthesis}

5,7-Dihydroxycoumarin (3): A mixture of phloroglucinol (1) $(2.00 \mathrm{~g}, 15.8 \mathrm{mmol}), \mathrm{ZnCl}_{2}(1.67 \mathrm{~g}, 12.3 \mathrm{mmol})$ and ethyl propiolate $(2)(1.9 \mathrm{~mL})$ was mixed together and stirred for $2 \mathrm{~h}$ at $100{ }^{\circ} \mathrm{C}$. Then the mixture was cooled and $5 \%$ hydrochloric acid $(40 \mathrm{~mL})$ was added. The precipitate was filtered off and washed with boiling $\mathrm{H}_{2} \mathrm{O}$ and purified by flash column chromatography using $10 \% \mathrm{MeOH}: \mathrm{CH}_{2} \mathrm{Cl}_{2}$ to give $3(1.29 \mathrm{~g}, 85 \%)$. ${ }^{1} \mathrm{H}$ NMR $\left(\mathrm{CDCl}_{3}-\mathrm{CD}_{3} \mathrm{OD}, 400 \mathrm{MHz}\right) \delta 7.99(1 \mathrm{H}, \mathrm{d}, J=9.6$ Hz, H-4), 6.23 (1H, s, H-8), $6.16(1 \mathrm{H}, \mathrm{d}, J=2.4 \mathrm{~Hz}, \mathrm{H}-6)$, $6.00(1 \mathrm{H}, \mathrm{d}, J=9.6 \mathrm{~Hz}, \mathrm{H}-3) ;{ }^{13} \mathrm{C}$ NMR $\left(\mathrm{CDCl}_{3}\right) \delta 163.4$, 161.9, 156.5, 155.9, 140.4, 108.4, 102.8, 98.4, 94.6; MS m/z $179.04[\mathrm{M}+\mathrm{H}]^{+}$(calcd. for $\mathrm{C}_{9} \mathrm{H}_{6} \mathrm{O}_{4}+\mathrm{H}, 179.03$ ).

5-Hydroxyseselin (4), 7-hydroxyalloxanthyletin (5) and dipetalolactone (6): To a solution of 5,7-dihydroxycoumarin (3) $(1.5 \mathrm{~g}, 8.4 \mathrm{mmol})$ in dry pyridine $(3.0 \mathrm{~mL})$ was added 3-methyl-2-butenal $(1.7 \mathrm{~mL}, 17.6 \mathrm{mmol})$ and the reaction mixture was stirred for $4 \mathrm{~h}$ at $115^{\circ} \mathrm{C}$. Then, the reagents were removed under reduced pressure. The solid residue was submitted to flash column chromatography with gradient elution of $\mathrm{MeOH}: \mathrm{CH}_{2} \mathrm{Cl}_{2}$ (0.1-5.0\%) to afford 5-hydroxyseselin (4) (411 $\mathrm{mg}, 20 \%$ ) as the major product, 7-hydroxyalloxanthyletin (5) (164 mg, $8 \%$ ) and dipetalolactone (6) (156 mg, 6\%) and $50 \%$ recovered starting material.

5-Hydroxyseselin (4): ${ }^{1} \mathrm{H}$ NMR $\left(\mathrm{CDCl}_{3}-\mathrm{CD}_{3} \mathrm{OD}, 400\right.$ $\mathrm{MHz}) \delta 7.96(1 \mathrm{H}, \mathrm{d}, J=9.6 \mathrm{~Hz}, \mathrm{H}-4), 6.71(1 \mathrm{H}, \mathrm{d}, J=10 \mathrm{~Hz}$, H-3'), 6.12 (1H, s, H-6), $6.04(1 \mathrm{H}, \mathrm{d}, J=9.6 \mathrm{~Hz}, \mathrm{H}-3), 5.5$ $(1 \mathrm{H}, \mathrm{d}, J=10 \mathrm{~Hz}, \mathrm{H}-4), 1.38\left(6 \mathrm{H}, \mathrm{s}, 2 \mathrm{CH}_{3}\right) ;{ }^{13} \mathrm{C} \mathrm{NMR} \delta 162.5$, 157.3, 155.1, 150.8, 140.1, 127.2, 114.9, 109.2, 103.4, 101.9, 98.9, 77.7, 27.9; MS m/z 245.08 $[\mathrm{M}+\mathrm{H}]^{+}$(calcd. for $\left.\mathrm{C}_{14} \mathrm{H}_{12} \mathrm{O}_{4}+\mathrm{H}, 245.08\right)$.

7-Hydroxyalloxanthyletin (5): ${ }^{1} \mathrm{H} \mathrm{NMR}\left(\mathrm{CDCl}_{3}\right.$ $\left.\mathrm{CD}_{3} \mathrm{OD}, 400 \mathrm{MHz}\right) \delta 7.91(1 \mathrm{H}, \mathrm{d}, J=9.6 \mathrm{~Hz}, \mathrm{H}-4), 6.57(1 \mathrm{H}$, $\mathrm{d}, J=10 \mathrm{~Hz}, \mathrm{H}-3$ '), $6.25(1 \mathrm{H}, \mathrm{s}, \mathrm{H}-8), 6.00(1 \mathrm{H}, \mathrm{d}, J=9.2 \mathrm{~Hz}$, $\mathrm{H}-3), 5.47(1 \mathrm{H}, \mathrm{d}, J=10 \mathrm{~Hz}, \mathrm{H}-4), 1.39\left(6 \mathrm{H}, \mathrm{s}, 2 \mathrm{CH}_{3}\right) ;{ }^{13} \mathrm{C}$ NMR $\delta 162.8,157.0,156.3,150.7,139.6,127.1,116.2,109.5$, 106.1, 102.9, 95.0, 77.7, 27.8; MS m/z 245.08 [M + H $]^{+}$(calcd. for $\left.\mathrm{C}_{14} \mathrm{H}_{12} \mathrm{O}_{4}+\mathrm{H}, 245.08\right)$.

Dipetalolactone (6): ${ }^{1} \mathrm{H} \mathrm{NMR}\left(\mathrm{CDCl}_{3}, 400 \mathrm{MHz}\right) \delta 7.93$ $(1 \mathrm{H}, \mathrm{d}, J=9.6 \mathrm{~Hz}, \mathrm{H}-4), 6.78(1 \mathrm{H}, \mathrm{d}, J=10 \mathrm{~Hz}, \mathrm{H}-4$ '), 6.61 $(1 \mathrm{H}, \mathrm{d}, J=10 \mathrm{~Hz}, \mathrm{H}-4 "), 6.11(1 \mathrm{H}, \mathrm{d}, J=9.6 \mathrm{~Hz}, \mathrm{H}-3), 5.57$ $\left(1 \mathrm{H}, \mathrm{d}, J=10 \mathrm{~Hz}, \mathrm{H}-3^{\prime}\right), 5.54$ (1H, d, $\left.J=10 \mathrm{~Hz}, \mathrm{H}-3 "\right), 1.45$ $\left(6 \mathrm{H}, \mathrm{s}, 2 \mathrm{CH}_{3}\right) ;{ }^{13} \mathrm{C}$ NMR $\delta 161.3,151.9,150.1,138.8,127.7$, $127.5,115.9,115.2,110.6,105.9,103.2,102.3,78.0,28.2$, 28.1; $\mathrm{MS} \mathrm{m} / z 311.13[\mathrm{M}+\mathrm{H}]^{+}$(calcd. for $\mathrm{C}_{19} \mathrm{H}_{18} \mathrm{O}_{4}+\mathrm{H}, 311.13$ ).

5-Prenyloxyseselin (7): A mixture of 5-hydroxyseselin (4) (300 mg, $1.22 \mathrm{mmol}), \mathrm{K}_{2} \mathrm{CO}_{3}(765 \mathrm{mg}, 9.5 \mathrm{mmol}$ ), 3,3dimethylallyl bromide $(0.2 \mathrm{~mL}, 1.73 \mathrm{mmol})$ and acetone $(20$ $\mathrm{mL}$ ) was refluxed with stirring for $1 \mathrm{~h}$. The solvent was evaporated and the residue was partitioned between EtOAc and brine, the organic layer was washed with $5 \% \mathrm{Na}_{2} \mathrm{CO}_{3}$, brine, dried and evaporated. The residue was purified by flash column chromatography with $90 \% \mathrm{CH}_{2} \mathrm{Cl}_{2}$ : hexane and gave 5- prenyloxyseselin (7) $(340 \mathrm{mg}, 89 \%)$. ${ }^{1} \mathrm{H}$ NMR $\left(\mathrm{CDCl}_{3}, 400\right.$ $\mathrm{MHz}) \delta 7.95(1 \mathrm{H}, \mathrm{d}, J=9.6 \mathrm{~Hz}, \mathrm{H}-4), 6.76(1 \mathrm{H}, \mathrm{d}, J=10 \mathrm{~Hz}$, H-3'), 6.20 (1H, s, H-6), 6.07 (1H, d, $J=9.6 \mathrm{~Hz}, \mathrm{H}-3), 5.54$ $(1 \mathrm{H}, \mathrm{d}, J=10 \mathrm{~Hz}, \mathrm{H}-4$ '), 5.47 (1H, br t, H-2"), $4.52(2 \mathrm{H}, \mathrm{d}$, $J=6.4 \mathrm{~Hz}, \mathrm{H}-1 "), 1.78\left(6 \mathrm{H}, \mathrm{s}, 2 \mathrm{CH}_{3}\right) .1 .43\left(6 \mathrm{H}, \mathrm{s}, 2 \mathrm{CH}_{3}\right) ;{ }^{13} \mathrm{C}$ NMR $\delta 161.4,157.3,155.9,151.1,139.3,139.0,127.4,118.6$, $115.0,110.2,103.9,102.5,96.3,77.9,28.1,25.8,18.2 ; \mathrm{MS}$ $\mathrm{m} / \mathrm{z} 313.14[\mathrm{M}+\mathrm{H}]^{+}$(calcd. for $\mathrm{C}_{19} \mathrm{H}_{20} \mathrm{O}_{4}+\mathrm{H}, 313.14$ ).

7-Prenyloxyalloxanthyletin (8): Compound 8 (60 mg, $96 \%$ ) was synthesized with the same procedure as compound 7. ${ }^{1} \mathrm{H}$ NMR $\left(\mathrm{CDCl}_{3}, 400 \mathrm{MHz}\right) \delta 7.93(1 \mathrm{H}, \mathrm{d}, J=9.6 \mathrm{~Hz}$, H-4), 6.12 (1H, d, J = $10 \mathrm{~Hz}, \mathrm{H}-3$ '), 6.32 (1H, br s, OH), 6.12 $(1 \mathrm{H}, \mathrm{d}, J=9.6 \mathrm{~Hz}, \mathrm{H}-3), 5.52\left(1 \mathrm{H}, \mathrm{d}, J=10 \mathrm{~Hz}, \mathrm{H}-4{ }^{\prime}\right), 5.43$ (1H, br t, H-2"), 4.54 (2H, d, J = 5.6 Hz, H-1"), $1.74(6 \mathrm{H}, \mathrm{s}$, $\left.2 \mathrm{CH}_{3}\right), 1.43\left(6 \mathrm{H}, \mathrm{s}, 2 \mathrm{CH}_{3}\right) ;{ }^{13} \mathrm{C} \mathrm{NMR} \delta 161.6,157.6,155.7$, 150.2, 138.6, 127.4, 118.8, 116.3, 110.9, 106.7, 103.6, 96.3, 92.5, 77.6, 65.7, 27.9, 25.7, 18.3; MS m/z $313.14[\mathrm{M}+\mathrm{H}]^{+}$ (calcd. for $\mathrm{C}_{19} \mathrm{H}_{20} \mathrm{O}_{4}+\mathrm{H}, 313.14$ ).

5-Acetoxy-6-(1,1-dimethylallyl)seselin (9): A mixture of 5-prenyloxyseselin (7) (340 mg, $1.09 \mathrm{mmol}$ ), NaOAc (465 $\mathrm{mg}, 9.7 \mathrm{mmol})$ and $\mathrm{Ac}_{2} \mathrm{O}(10 \mathrm{~mL}$, excess $)$ was refluxed with stirring for $20 \mathrm{~h}$. The cooled mixture was filtered and washed with EtOAc. The combined filtrates were evaporated and purified by flash column chromatograph with $5 \%$ EtOAc: hexane to give 5-acetoxy-6-(1,1-dimethylallyl)seselin (9) (365 mg, $94 \%)$. ${ }^{1} \mathrm{H}$ NMR $\left(\mathrm{CDCl}_{3}, 400 \mathrm{MHz}\right) \delta 7.41(1 \mathrm{H}, \mathrm{d}, J=9.6$ Hz, H-4), 6.84 (1H, d, $J=10$ Hz, H-3'), 6.25 (1H, dd, $J=17.4$, $10.6 \mathrm{~Hz}, \mathrm{H}-2 "), 6.20(1 \mathrm{H}, \mathrm{d}, J=9.6 \mathrm{~Hz}, \mathrm{H}-3), 5.73(1 \mathrm{H}, \mathrm{d}, J=$ $10 \mathrm{~Hz}, \mathrm{H}-4$ '), 4.92 (1H, d, J = $17.4 \mathrm{~Hz}, \mathrm{H}-3$ "b), 4.86 (1H, d, $J=10.6 \mathrm{~Hz}, \mathrm{H}-3 " \mathrm{a}), 2.20$ (3H, s, OAc), $1.50\left(6 \mathrm{H}, \mathrm{s}, 2 \mathrm{CH}_{3}\right)$, $1.25\left(6 \mathrm{H}, \mathrm{s}, 2 \mathrm{CH}_{3}\right) ;{ }^{13} \mathrm{C} \mathrm{NMR} \delta 169.4,160.4,155.7,149.1$, 148.9, 144.8, 138.4, 129.6, 125.4, 115.1, 113.0, 108.2, 106.9, 106.9, 78.4, 41.1, 27.8, 21.1; MS m/z 355.15 [M + H] ${ }^{+}$(calcd. for $\left.\mathrm{C}_{21} \mathrm{H}_{22} \mathrm{O}_{5}+\mathrm{H}, 355.15\right)$.

7-Acetoxy-8-(1,1-dimethylallyl)alloxanthyletin (10): Compound $\mathbf{1 0}$ (65 mg, $97 \%$ ) was synthesized in the same procedure as compound 9. ${ }^{1} \mathrm{H} \mathrm{NMR}\left(\mathrm{CDCl}_{3}, 400 \mathrm{MHz}\right) \delta 8.03$ $(1 \mathrm{H}, \mathrm{d}, J=9.6 \mathrm{~Hz}, \mathrm{H}-4), 6.27(1 \mathrm{H}, \mathrm{dd}, J=17.4,10.6 \mathrm{~Hz}$, H-2"), $6.28(1 \mathrm{H}, \mathrm{d}, J=9.6 \mathrm{~Hz}, \mathrm{H}-3), 6.13(1 \mathrm{H}, \mathrm{d}, J=10 \mathrm{~Hz}$, H-3'), $5.61(1 \mathrm{H}, \mathrm{d}, J=10 \mathrm{~Hz}, \mathrm{H}-4 '), 4.96(1 \mathrm{H}, \mathrm{d}, J=17.4 \mathrm{~Hz}$, H-3"b), 4.89 (1H, d, $J=10.6 \mathrm{~Hz}, \mathrm{H}-3$ "a), 2.24 (3H, s, OAc), $1.61\left(6 \mathrm{H}, \mathrm{s}, 2 \mathrm{CH}_{3}\right), 1.55\left(6 \mathrm{H}, \mathrm{s}, 2 \mathrm{CH}_{3}\right) ;{ }^{13} \mathrm{C} \mathrm{NMR} \delta 168.9$, 160.2, 153.4, 148.8, 148.6, 147.3, 138.4, 130.0, 120.3, 116.1, 113.4, 110.8, 108.1, 107.2, 77.8, 41.1, 21.1; MS m/z 355.15 $[\mathrm{M}+\mathrm{H}]^{+}$(calcd. for $\left.\mathrm{C}_{21} \mathrm{H}_{22} \mathrm{O}_{5}+\mathrm{H}, 355.15\right)$.

5-Hydroxy-6-(1,1-dimethylallyl)seselin (11): The solution of 5-acetoxy-6-(1,1-dimethylallyl)seselin (9) (365 mg, $1.03 \mathrm{mmol})$ in $\mathrm{MeOH}(5 \mathrm{~mL})$ and $1 \% \mathrm{NaOH}$ in $\mathrm{MeOH}(8.2$ $\mathrm{mL}, 2.06 \mathrm{mmol}$ ) was stirred at room temperature for $3 \mathrm{~h}$. The solution was neutralized with $5 \% \mathrm{HCl}$ then evaporated and the residue was partitioned between EtOAc and brine. The EtOAc layer was washed with brine, dried, evaporated and the residue was submitted to flash column chromatography $\left(\mathrm{CH}_{2} \mathrm{Cl}_{2}\right.$ to $5 \%$ EtOAc: $\left.\mathrm{CH}_{2} \mathrm{Cl}_{2}\right)$ to give 5-hydroxy-6-(1,1-

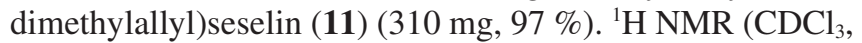
$400 \mathrm{MHz}) \delta 7.88(1 \mathrm{H}, \mathrm{d}, J=9.6 \mathrm{~Hz}, \mathrm{H}-4), 6.74(1 \mathrm{H}, \mathrm{d}, J=10$ Hz, H-3'), 7.25 (1H, br s, OH), $6.63(1 \mathrm{H}, \mathrm{dd}, J=17.8,10.4$ Hz, H-2"), 6.03 (1H, d, $J=9.6 \mathrm{~Hz}, \mathrm{H}-3), 5.51(1 \mathrm{H}, \mathrm{d}, J=10$ 
Hz, H- 4'), 5.42 (1H, d, $J=17.8$ Hz, H-3"b), 5.33 (1H, d, $J=$ $10.4 \mathrm{~Hz}, \mathrm{H}-3$ "a), 1.57 (6H, s, $\left.2 \mathrm{CH}_{3}\right), 1.47\left(6 \mathrm{H}, \mathrm{s}, 2 \mathrm{CH}_{3}\right) ;{ }^{13} \mathrm{C}$ NMR $\delta 161.4,155.9,152.1,149.5,149.4,139.8,127.1,115.6$, 115.2, 113.6, 110.8, 103.7, 103.3, 77.7, 41.1, 27.6, 27.5; MS $\mathrm{m} / \mathrm{z} 313.14[\mathrm{M}+\mathrm{H}]^{+}$(calcd. for $\mathrm{C}_{19} \mathrm{H}_{20} \mathrm{O}_{4}+\mathrm{H}, 313.14$ ).

7-Hydroxy-8-(1,1-dimethylallyl)alloxanthyletin (12): Compound 12 (55 mg, $96 \%$ ) was synthesized with the same procedure as compound 11. ${ }^{1} \mathrm{H}$ NMR $\left(\mathrm{CDCl}_{3}, 400 \mathrm{MHz}\right) \delta$ $7.99(1 \mathrm{H}, \mathrm{d}, J=9.6 \mathrm{~Hz}, \mathrm{H}-4), 7.33$ (br s, OH), $6.60(1 \mathrm{H}, \mathrm{d}, J=$ $10 \mathrm{~Hz}, \mathrm{H}-3$ '), 6.46 (1H, dd, $J=18,10 \mathrm{~Hz}, \mathrm{H}-2 "), 6.12$ ( 1H, d, $J=9.6 \mathrm{~Hz}, \mathrm{H}-3), 5.52(1 \mathrm{H}, \mathrm{d}, J=10 \mathrm{~Hz}, \mathrm{H}-3 \mathrm{a}), 5.49$ (1H, d, $J=18 \mathrm{~Hz}, \mathrm{H}-3$ "b), 5.40 (1H, d, $J=10 \mathrm{~Hz}, \mathrm{H}-4$ '), 1.68 (6H, s, $\left.2 \mathrm{CH}_{3}\right), 1.55\left(6 \mathrm{H}, \mathrm{s}, 2 \mathrm{CH}_{3}\right) ;{ }^{13} \mathrm{C} \mathrm{NMR} \delta 161.2,154.3,153.9$, 149.3, 149.1, 139.1, 127.7, 116.5, 113.8, 111.0, 110.0, 106.5, 103.9, 77.5, 41.0, 28.0, 27.6; HRMS $m / z 313.1440[\mathrm{M}+\mathrm{H}]^{+}$ (calcd. for $\mathrm{C}_{19} \mathrm{H}_{20} \mathrm{O}_{4}+\mathrm{H}, 313.1436$ ).

Nordentatin (13): The solution of 5-hydroxy-6-(1,1dimethylallyl)seselin (11) (300 mg, $0.96 \mathrm{mmol})$ in $\mathrm{MeOH}$ (5 $\mathrm{mL})$ and $1 \% \mathrm{NaOH}$ in $\mathrm{MeOH}(8.2 \mathrm{~mL}, 2.06 \mathrm{mmol})$ was stirred at room temperature for $20 \mathrm{~h}$. The solution was neutralized with $5 \% \mathrm{HCl}$ then evaporated and the residue was partitioned between EtOAc and brine. The EtOAc layer was washed with brine, dried, evaporated and the residue was submitted to flash column chromatography $\left(\mathrm{CH}_{2} \mathrm{Cl}_{2}\right.$ to $5 \%$ EtOAc: $\left.\mathrm{CH}_{2} \mathrm{Cl}_{2}\right)$ to give nordentatin (13) (294 mg, $98 \%$ ). Pale yellow amorphous solid; m.p. $179-181^{\circ} \mathrm{C}$, IR (KBr, $\left.\nu_{\max }, \mathrm{cm}^{-1}\right)$ : 3248, 2974, 1685, $1605,1588,1559,1318,1178,1138 ;{ }^{1} \mathrm{H}$ NMR $\left(\mathrm{CDCl}_{3}\right) \delta 8.04$ $(1 \mathrm{H}, \mathrm{d}, J=9.6 \mathrm{~Hz}, \mathrm{H}-4), 6.55(1 \mathrm{H}, \mathrm{d}, J=9.9 \mathrm{~Hz}, \mathrm{H}-6), 6.38$ $\left.(1 \mathrm{H}, \mathrm{s}, \mathrm{OH}), 6.27(1 \mathrm{H}, \mathrm{dd}, J=17.4,10.6 \mathrm{~Hz}, \mathrm{H}-2)^{\prime}\right), 6.13(1 \mathrm{H}$, $\mathrm{d}, J=9.6 \mathrm{~Hz}, \mathrm{H}-3), 5.67(1 \mathrm{H}, \mathrm{d}, J=9.9 \mathrm{~Hz}, \mathrm{H}-7), 4.91(1 \mathrm{H}, \mathrm{d}$, $J=17.4 \mathrm{~Hz}, \mathrm{H}-3$ 'b), 4.84 (1H, d, $J=10.6 \mathrm{~Hz}, \mathrm{H}-3 \mathrm{a}), 1.63$ $\left(6 \mathrm{H}, \mathrm{s}, \mathrm{C}-4\right.$ ' and C-5'), $1.43\left(6 \mathrm{H}, \mathrm{s}, 2 \mathrm{CH}_{3}-8\right) ;{ }^{13} \mathrm{C}$ NMR $\delta 161.7$ (C-2), 156.0 (C-9a), 154.1 (C-1a), 150.0 (C-2'), 146.8 (C-5), 139.5 (C-4), 129.8 (C-7), 116.0 (C-10), 115.2 (C-6), 110.0 (C-3), 108.0 (C-3'), 106.2 (C-5a), 104.0 (C-4a), 77.1 (C-8), 41.0 (C-1'), 29.5 (C-4' and C-5'), $27.3\left(2 \mathrm{CH}_{3}-8\right)$. HRMS $\mathrm{m} / \mathrm{z}$ $313.1436[\mathrm{M}+\mathrm{H}]^{+}$(calcd. for $\mathrm{C}_{19} \mathrm{H}_{20} \mathrm{O}_{4}+\mathrm{H}, 313.1440$ ).

\section{Bioassay}

Cytotoxicity assay: Cytotoxicity assay against human epidermoid carcinoma (KB), breast adenocarcinoma (MCF7) and human small cell lung cancer (NCI-H187) cell lines were performed employing Resazurin Microplate Assay $\left(\right.$ REMA) ${ }^{12}$ while cytotoxicity assay against Vero cells (African green monkey kidney) was performed by Green Fluorescent Protein (GFP) based assay ${ }^{13}$. Ellipticine was included as a reference substance.

\section{RESULTS AND DISCUSSION}

5,7-Dihydroxycoumarin (3), obtained from the reaction between phloroglucinol (1) and ethyl propiolate (2) using $\mathrm{ZnCl}_{2}$ as a catalyst at $100{ }^{\circ} \mathrm{C}$, was used as the starting material (Scheme-I). Alkylation of compound 3 with 3-methylcrotonaldehyde in the presence of pyridine for $4 \mathrm{~h}$ provided the mixture of pyranocoumarins 4 (20\%), 5 (8 \%) and dipetalolactone (6) (6\%) (Scheme-II) and $50 \%$ recovered starting material. Prolonging the reaction time or the excess amount of 3-methylcrotonaldehyde led to 6 as a major product ${ }^{14}$. Pyranocoumarins $\mathbf{4}$ and $\mathbf{5}$ were treated with 3,3-dimethylallyl

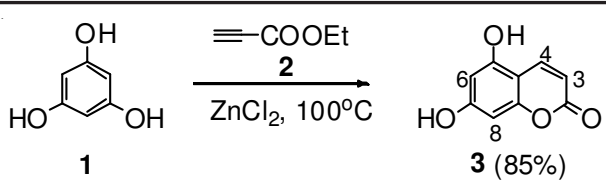

Scheme-I: Synthesis of 5,7-dihydroxycoumarin (3)

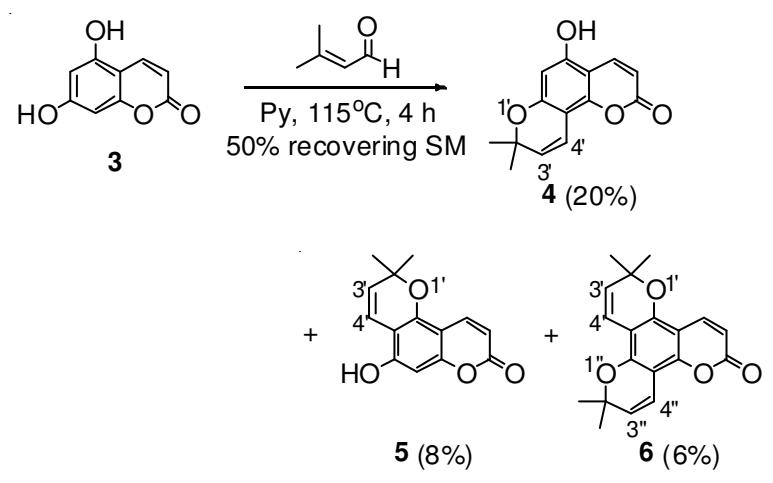

Scheme-II: Synthesis of pyranocoumarins 4, 5 and $\mathbf{6}$

bromide in the presence of $\mathrm{K}_{2} \mathrm{CO}_{3}$ and yielded O-alkylation products $\mathbf{7}$ and $\mathbf{8}$, respectively (Scheme-III). After treatment of 7 and $\mathbf{8}$ with $\mathrm{Ac}_{2} \mathrm{O}$ in the presence of $\mathrm{NaOAc}$, Claisen rearrangement occurred to provide 9 and 10, respectively, in high yield (Scheme-IV). Hydrolysis of acetyl group using $1 \%$ $\mathrm{NaOH}$ in $\mathrm{MeOH}$ for $3 \mathrm{~h}$ furnished the corresponding phenolic compounds 5- and 7-hydroxy pyranocoumarins $\mathbf{1 1}$ and $\mathbf{1 2}$ in high yield (Scheme-V). Saponification and recyclization of 11 using $1 \% \mathrm{NaOH}$ in $\mathrm{MeOH}$ for $20 \mathrm{~h}$ provided nordentatin in $98 \%$ yield.

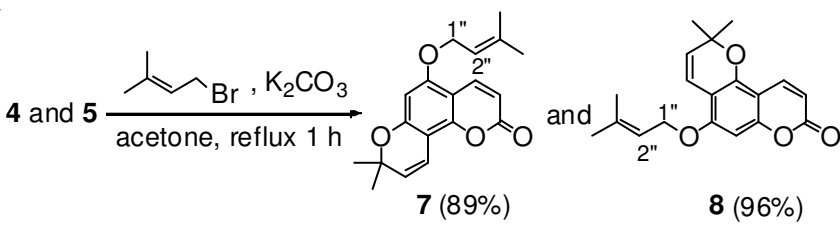

Scheme-III: O-Alkylation of compounds $\mathbf{4}$ and $\mathbf{5}$

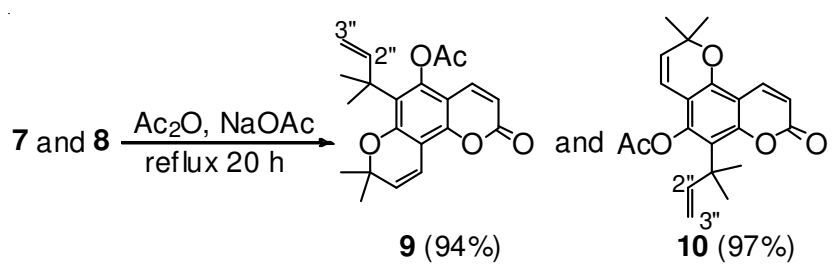

Scheme-IV: Synthesis of acetylated compounds $\mathbf{9}$ and $\mathbf{1 0}$

In our previous report, the cytotoxicity of nordentatin against cancer cells, NCI-H187 and KB cell, showed the $\mathrm{IC}_{50}$ values ranging from $3-6 \mathrm{mg} / \mathrm{mL}$ and it exhibited cytotoxicity against normal cells, Vero cells, with an $\mathrm{IC}_{50}$ of $17.60 \mathrm{mg} / \mathrm{mL}^{5}$. Unfortunatedly, nordentatin was found in a small amount in a natural source as usual and we tried to synthesize this compound for the other biological activities testing. Moreover, all adducts from each steps were also evaluated for cytotoxicity as well (Table-1). It was found that some of them were natural compounds which showed some activities.

Compound 4 showed cytotoxicity against KB cells with an $\mathrm{IC}_{50}$ value of $3.94 \mathrm{mg} / \mathrm{mL}$ while it showed weak activity against the other cell lines. This means the structure of coumarin 


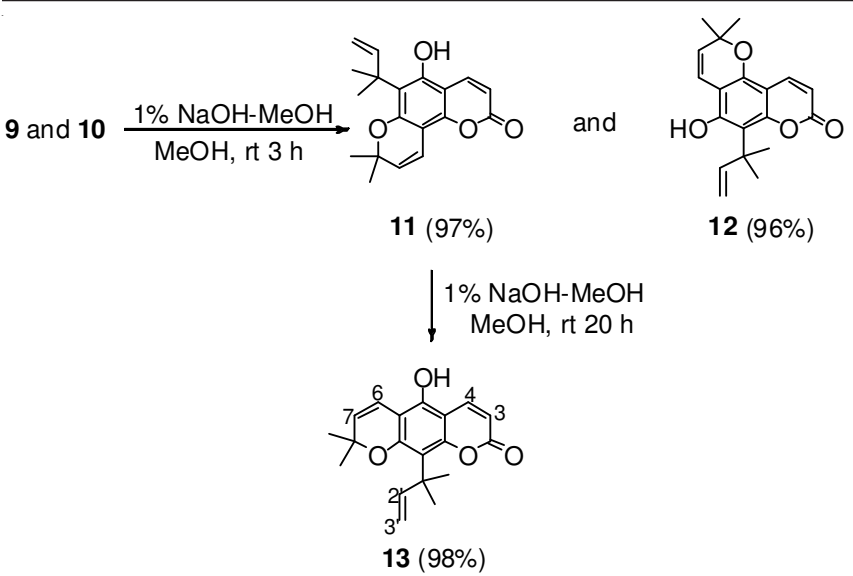

Scheme-V: Synthesis of nordentatin

4 displayed selective cytotoxicity against $\mathrm{KB}$ cells. On the other hand, compound $\mathbf{5}$ showed moderate to weak activity against all cell lines. The results showed convincingly that the hydroxyl group at the C-5 position may play an important role in cytotoxicity. Coumarin $\mathbf{6}$ exhibited cytotoxicity against NCI-H187 cell line with an $\mathrm{IC}_{50}$ value of $5.18 \mathrm{mg} / \mathrm{mL}$ while it showed weak cytotoxicity to the other cell lines. It seems that this compound is selectively active on the NCI-H187 cell line. Coumarin 7 showed cytotoxicity against NCI-H187 cell line with an $\mathrm{IC}_{50}$ value of $5.78 \mathrm{mg} / \mathrm{mL}$ which stronger than the starting compound 4 . This may be explained that the prenyl group is favorable to the NCI-H187 cells. In contrast, the cytotoxicity of compound 7 showed weak activity against KB cell line with an $\mathrm{IC}_{50}$ value of $17.34 \mathrm{mg} / \mathrm{mL}$. It means that the prenyl group at the $\mathrm{C}-5$ position is selectively active on only the NCI-H187 cell line. In contrast to compound 7, compound 8 is inactive against the NCI-H187 cell line which means prenyl group at the $\mathrm{C}-7$ position appears to be detrimental to the activity against this cell line. However, compound $\mathbf{8}$ exhibited stronger cytotoxicity than the parent $\mathbf{5}$. It seems that prenyl group at the $\mathrm{C}-7$ position is selectively active on the $\mathrm{KB}$ cell line. Acetoxy derivative $\mathbf{9}$ showed the same cytotoxicity as the parent 7 against the NCI-H187 and KB cell lines but showed stronger activity against the MCF-7 and Vero cell lines. On the other hand, compound $\mathbf{1 0}$ exhibited inactive against all cell lines. The results show convincingly that the positions of pyrano, acetoxy and 1,1-dimethylallyl groups are essential for cytotoxicity. Compounds $\mathbf{1 1}$ and $\mathbf{1 2}$ showed the same activity against all cell lines with $\mathrm{IC}_{50}$ of around $13-26 \mu \mathrm{g} / \mathrm{mL}$. Considering the cytotoxicity of all derivatives against the NCIH187 cell line, compounds 6, 7,9 and 13 showed strong cytotoxicity with $\mathrm{IC}_{50}$ ranging of $3-7 \mu \mathrm{g} / \mathrm{mL}$. Unfortunatedly, the rest of the derivatives showed moderate to weak cytotoxicity. Comparing between compounds $\mathbf{1 1}$ and 13, it is suggested that the linear skeleton of coumarin is favorable for cytotoxicity against cancer cell lines. Cytotoxicity of all derivatives displayed moderate to inactive against the MCF-7 cell line, although nordentatin showed cytotoxic activity with an $\mathrm{IC}_{50}$ value of $10.68 \mu \mathrm{g} / \mathrm{mL}$.
Interestingly, coumarin 4 showed cytotoxic activity against the $\mathrm{KB}$ cell line with an $\mathrm{IC}_{50}$ value of $3.94 \mu \mathrm{g} / \mathrm{mL}$ and showed very weak activity against Vero cells $\left(\mathrm{IC}_{50}=47.04 \mu \mathrm{g} / \mathrm{mL}\right)$. The results show convincingly that this compound is likely to be useful as a lead compound for the development of cytotoxic agents. In addition, compound $\mathbf{7}$ showed cytotoxicity against the NCI-H187 cell line with an $\mathrm{IC}_{50}$ value of $5.78 \mathrm{mg} / \mathrm{mL}$ and exhibited non-cytotoxicity against the normal cell (Vero cells). The results indicate that coumarin 7 may be one of the new lead compounds for the development as anticancer agents.

\section{Conclusion}

Eleven coumarins derivatives were synthesized and evaluated for cytotoxicity against cancer cells (KB, NCI-H187 and MCF-7) and also normal cell (Vero cell). It was found that compounds $6,7,9$ and 13 exhibited strong cytotoxicity against NCI-H187 cell lines. For the KB cell line, compounds $\mathbf{4}$ and 13 showed strong cytotoxicity against this cell line. Interestingly, compounds $\mathbf{4}$ and $\mathbf{7}$ may be one of the new lead compounds for the development of anticancer agents.

\section{ACKNOWLEDGEMENTS}

The National Research University Project of Thailand through the Advanced Functional Materials Cluster of Khon Kaen University and the Center of Excellence for Innovation in Chemistry (PERCH-CIC), Office of the Higher Education Commission, Ministry of Education are gratefully acknowledged for financial support. Thanks are also due to The Bioassay Laboratory of the National Center for Genetic Engineering and Biotechnology, Pathumthani, Thailand, for biological activity assays.

\section{REFERENCES}

1. C. Yenjai and S. Wanich, Bioorg. Med. Chem. Lett., 20, 2821 (2010).

2. U. Songsiang, S. Pitchuanchom, C. Boonyarat, C. Hahnvajanawong and C. Yenjai, Eur. J. Med. Chem., 45, 3794 (2010).

3. T. Thongthoom, P. Promsuwan and C. Yenjai, Eur. J. Med. Chem., 46, 3755 (2011).

4. C. Yenjai, S. Sripontan, P. Sriprajun, P. Kittakoop, A. Jintasirikul, M. Tanticharoen and Y. Thebtaranonth, Planta Med., 66, 277 (2000).

5. U. Songsiang, T. Thongthoom, C. Boonyarat and C. Yenjai, J. Nat. Prod., 74, 208 (2011).

6. T. Thongthoom, U. Songsiang, C. Phaosiri and C. Yenjai, Arch. Pharm. Res., 33, 675 (2010).

7. K. Noipha, T. Thongthoom, U. Songsiang, C. Boonyarat and C. Yenjai, Diabetes Res. Clin. Pract., 90, e67 (2010).

8. T. Nakamura, N. Kodama, Y. Arai, T. Kumamoto, Y. Higuchi, C. Chaichantipyuth, T. Ishikawa, K. Ueno and S. Yano, J. Nat. Med., 63, 21 (2009).

9. Z. Luo, L. Boonyaratanakornkit, C.T. Che, C.A.J. Erdelmeier, H.H.S. Fong and N.R. Farnsworth, J. Nat. Prod., 6, 1161 (1986).

10. Y.Y. Chan, C.H. Li, Y.C. Shen and T.S. Wu, Chem. Pharm. Bull., 58, 61 (2010).

11. A. Murakami, G. Gao, M. Omura, M.Yano, C. Ito, H. Furukawa, D. Takahashi, K. Koshimizu and H. Ohigashi, Bioorg. Med. Chem. Lett., 10, 59 (2000).

12. E. Melliou, P. Magiatis, S. Mitaku, A. Skaltsounis, E. Chinou and I. Chinou, J. Nat. Prod., 68, 78 (2005).

13. J.O. Brien, I. Wilson, T. Orton and F. Pognan, Eur. J. Biochem., 267, 5421 (2000).

14. L. Hunt, M. Jordan, M. De Jesus and F.M. Wurm, Biotechnol. Bioeng., 65, 201 (1999). 